\title{
Estimasi Value at Risk dalam Investasi Saham Subsektor Perbankan di Bursa Efek Indonesia dengan Pendekatan Extreme Value Theory
}

\author{
Salisa Minchatur Rohmah dan Agus Suharsono \\ Departemen Statistika, Fakultas MIPA, Institut Teknologi Sepuluh Nopember (ITS) \\ e-mail: agus_s@statistika.its.ac.id
}

\begin{abstract}
Abstrak-Investasi di pasar modal merupakan salah satu cara alternatif untuk meningkatkan aset sebesar-besarnya di masa mendatang dengan risiko tertentu. Salah satu aset financial yang banyak diminati adalah investasi dalam bentuk saham. Pengukuran risiko merupakan hal yang sangat penting berkaitan dengan investasi dana yang cukup besar. Dalam berinvestasi, investor diharapkan mampu mengestimasi tingkat risiko sebelum melakukan investasi. Oleh karena itu diperlukan penelitian untuk menghitung tingkat risiko pada bidang keuangan. Metode yang digunakan dalam menghitung risiko yaitu metode Value at Risk (VaR). Namun pada kenyataannya, data terkait bidang keuangan sering kali mengandung nilai-nilai ekstrem, sehingga diperlukan analisis lebih lanjut untuk mengatasi hal tersebut, yaitu dengan metode Extreme Value Theory (EVT). Pada penelitian ini, perhitungan tingkat risiko dilakukan dengan dua pendekatan EVT yaitu Block Maxima (BM) dan Peaks Over Threshold (POT). Diperoleh hasil tingkat risiko yang dihasilkan oleh metode BM lebih besar dibanding tingkat risiko dari POT. Namun hasil backtesting menyatakan bahwa metode POT lebih akurat dibanding metode BM.
\end{abstract}

Kata Kunci-Extreme Value Theory, Return Saham, Risiko, Value at Risk.

\section{PENDAHULUAN}

$\mathrm{P}$ ERKEMBANGAN perekonomian negara pada era globalisasi dipengaruhi oleh komponen-komponen yang ada dalam struktur ekonomi negara itu sendiri, salah satunya yakni pasar modal. Saat ini pasar modal telah menjadi leading indicator untuk melihat perkembangan perekonomian yang terjadi pada suatu negara, termasuk di Indonesia [1]. Tujuan dari investasi yaitu sebagai sarana alternative untuk meningkatkan asset di masa mendatang. Salah satu asset yang banyak diminati adalah investasi dalam bentuk saham. Dalam melakukan investasi, seorang investor akan memilih untuk menginvestasikan dana pada perusahaan yang memberikan rasa aman pada investasinya. Pada tingkat keamanan tersebut, seorang investor memiliki ekspektasi pengembalian (return) yang sebesar-besarnya pada tingkat risiko tertentu [2].

Saham perbankan merupakan saham yang paling diminati [3]. Seiring berjalannya waktu, sektor perbankan mampu membuktikan eksistensinya dalam kinerja dan pencapaian hasil yang cukup baik sehingga investor tertarik untuk membeli saham di sektor perbankan. Selain itu, saham-saham perbankan masih menjadi pendorong kenaikan indeks harga saham gabungan (IHSG), dan masuk dalam Forbes 2000 pada tahun 2015 dan 2016. Forbes 2000 the world biggest companies memuat 2000 daftar perusahaan publik terbesar di dunia. Adapun empat dari enam perusahaan dari Indonesia yang termuat dalam Forbes 2000, diantaranya adalah perusahaan perbankan.

Keadaan beberapa bank yang selalu naik dari tahun ke tahun menyebabkan banyak investor yang ingin berinvestasi pada sektor perbankan. Oleh karena itu, sebelum melakukan investasi pada perusahaan alangkah baiknya jika investor memiliki pemahaman yang baik tentang kemungkinan risiko yang dihasilkan oleh perusahaan tersebut. Salah satu cara yang dapat digunakan dalam mengestimasi risiko saham adalah metode Value at Risk (VaR). VaR merupakan alat ukur yang dapat menghitung kerugian terburuk yang dapat terjadi dengan mengetahui posisi asset dan tingkat kepercayaan akan terjadinya risiko [4].

Data deret waktu keuangan sebagian besar memiliki ekor distribusi yang gemuk (heavy tail) yaitu ekor distribusi turun secara lambat bila dibandingkan dengan disttibusi normal. Hal ini menyebabkan peluang terjadinya nilai ekstrem. Salah satu metode pengukuran risiko yang dapat menangkap keberadaan nilai ekstrem yang sering muncul pada data return saham yaitu metode estimasi VaR dengan pendekatan Extreme Value Theory (EVT) [5]. EVT memberi perhatian pada informasi kejadian-kejadian ekstrem berdasarkan nilai-nilai ekstrem yang diperoleh untuk membentuk fungsi sebaran dari nilainilai ekstrem tersebut. Terdapat dua metode yang digunakan untuk mengidentifikasi pergerakan nilai ekstrem, yaitu Block Maxima (BM) dan Peaks Over Threshold (POT) [6].

Pada penelitian ini bertujuan untuk menganalisis risiko return saham pada 4 perusahaan perbankan yang tergabung dalam BEI dan indeks LQ45 menggunakan VaR dengan pendekatan EVT, baik metode BM maupun POT.

\section{TINJAUAN PUSTAKA}

\section{A. Extreme Value Theory (EVT)}

EVT merupakan salah satu metode statistika yang digunakan untuk mempelajari bagaimana perilaku ekor (tail) suatu distribusi dari data yang mengandung nilai ekstrem. Metode EVT berfokus pada perilaku ekor (tail) suatu distribusi untuk menentukan probabilitas nilai-nilai ekstrem pada data heavy-tail yang tidak dapat dilakukan dengan pendekatan biasa. Dalam mengidentifikasi pergerakan nilai ekstrem terdapat dua pendekatan yang digunakan. Pendekatan pertama yaitu metode Block Maxima (BM) dan metode Peaks Over Threshold (POT) [7]. 


\section{B. Block Maxima (BM)}

Metode Block Maxima adalah metode yang dapat mengidentifikasi nilai ekstrem berdasarkan nilai tertinggi data observasi yang dikelompokkan berdasarkan periode tertentu. Setiap blok periode yang terbentuk selanjutnya ditentukan nilai yang paling tinggi. Data yang paling tinggi dimasukkan dalam sampel karena nilai inilah yang merupakan nilai ekstrem pada suatu periode tertentu [8]. Metode Block Maxima mengaplikasikan teorema Fisher-Tippet, Gnedenko (1928) bahwa data sampel nilai ekstrem yang diambil dari metode Block Maxima akan mengikuti distribusi Generalized Extreme Value (GEV) yang memiliki cumulative distribution function (cdf) sebagai berikut.

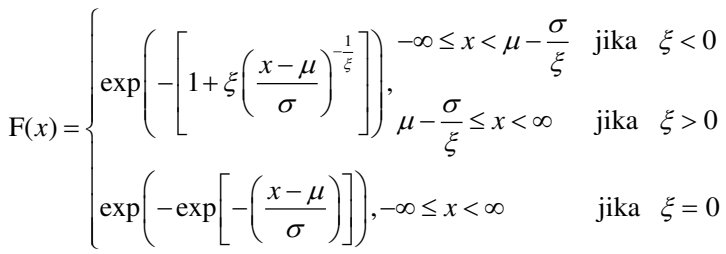

dengan $1+\xi\left(\frac{x-\mu}{\sigma}\right)>0 ;-\infty<\mu<\infty ; \sigma>0 ;-\infty<\xi<\infty$

$\mu=$ parameter lokasi

$\sigma=$ parameter skala

$\xi=$ parameter bentuk (shape) / tail index

\section{Peaks Over Threshold (POT)}

Dalam Extreme Value Theory (EVT), metode Peaks Over Threshold (POT) mengidentifikasi nilai ekstrem dengan cara menetapkan threshold tertentu dan mengabaikan waktu terjadinya event [8]. Nilai ekstim adalah data yang berada diatas threshold tersebut. Metode ini mengaplikasikan Picklands-Dalkema-De Hann Theorem yang menyatakan bahwa semakin tinggi threshold (u), maka distribusi untuk data diatas threshold (u) tersebut akan mengikuti distribusi Generalized Pareto Distribution (GPD) yang memiliki cummulative distribution function (cdf) sebagai berikut.

$$
\mathrm{F}(x)=\left\{\begin{array}{ccc}
1-\left(1+\xi \frac{x-\mu}{\sigma}\right)^{-\frac{1}{\xi}}, 0 \leq x-\mu<-\frac{\sigma}{\xi} & \text { jika } & \xi<0 \\
0 \leq x-\mu<\infty & \text { jika } & \xi>0 \\
1-\exp \left(-\frac{x-\mu}{\sigma}\right), 0 \leq x-\mu<\infty & \text { jika } & \xi=0
\end{array}\right.
$$

dengan $1+\frac{\xi x}{\sigma}>0 ; x>\mu ; \sigma>0 ;-\infty<\xi<\infty$

$\sigma=$ parameter skala

$\xi=$ parameter bentuk (shape) / tail index

\section{Estimasi Parameter GEV}

Penaksir parameter metode GEV dapat ditaksir dengan menggunakan metode Maximum Likelihood Estimation (MLE) dengan membentuk probability density function (PDF) sebagai berikut.

$$
f(x, \mu, \sigma, \xi)=\left\{\begin{array}{l}
\frac{1}{\sigma}\left[1+\xi\left(\frac{x-\mu}{\sigma}\right)\right]^{-\frac{1}{\xi}-1} \exp \left(-\left[1+\xi\left(\frac{x-\mu}{\sigma}\right)\right]^{-\frac{1}{\xi}}\right), \xi \neq 0 \\
\frac{1}{\sigma} \exp \left[-\left(\frac{x-\mu}{\sigma}\right)\right] \exp \left(-\exp \left[-\left(\frac{x-\mu}{\sigma}\right)\right]\right), \xi=0
\end{array}\right.
$$

Membuat fungsi likelihood

$$
L(\mu, \sigma, \xi)=\left(\frac{1}{\sigma}\right)^{n} \prod_{i=1}^{n}\left\{\left[1+\xi\left(\frac{x_{i}-\mu}{\sigma}\right)\right]^{-\frac{1}{\xi}-1}\right\} \exp \left(-\sum_{i=1}^{n}\left[1+\xi\left(\frac{x_{i}-\mu}{\sigma}\right)\right]^{\frac{1}{\xi}}\right)
$$

Membentuk fungsi ln likelihood

$$
\begin{aligned}
\ln \mathrm{L}(\mu, \sigma, \xi)= & -n \ln (\sigma)-\left(\frac{1}{\xi}+1\right) \sum_{i=1}^{n} \ln \left[1+\xi\left(\frac{x_{i}-\mu}{\sigma}\right)\right] \\
& -\sum_{i=1}^{n}\left[1+\xi\left(\frac{x_{i}-\mu}{\sigma}\right)\right]
\end{aligned}
$$

Mendapatkan nilai maksimum dari fungsi likelihood dengan membentuk turunan pertama dari ln likelihood terhadap parameter $(\mu, \sigma, \xi)$.

\section{E. Estimasi Parameter GPD}

Estimasi parameter metode GPD dapat ditaksir dengan menggunakan metode Maximum Likelihood Estimation (MLE) dengan PDF sebagai berikut.

$$
f(x)=\left\{\begin{array}{l}
\frac{1}{\sigma}\left(1+\xi \frac{x-\mu}{\sigma}\right)^{-\frac{1}{\xi}-1}, \xi \neq 0 \\
\frac{1}{\sigma} \exp \left(-\frac{x-\mu}{\sigma}\right), \xi=0
\end{array}\right.
$$

Fungsi likelihood

$$
L(\mu, \sigma, \xi)=\left(\frac{1}{\sigma}\right)^{n} \prod_{i=1}^{n}\left[1+\xi\left(\frac{x_{i}-\mu}{\sigma}\right)\right]^{-\frac{1}{\xi}-1}
$$

fungsi ln likelihood

$$
\ln L(u, \xi, \sigma)=-n \ln \sigma-\left(\frac{1}{\xi}+1\right) \sum_{i=1}^{n} \ln \left(1+\frac{\xi\left(x_{i}-u\right)}{\sigma}\right)
$$

memaksimumkan ln fungsi likelihood dengan cara mencari turunan pertama terhadap parameter distribusi $(\mu, \sigma, \xi)$.

\section{F. Uji Kesesuaian Distribusi}

Uji kesesuaian distribusi bertujuan untuk menunjukkan adanya kesesuaian distribusi teoritis. Uji Kolmogorov-Smirnov dilakukan dengan menyesuaikan fungsi distribusi empiris $\mathrm{S}(\mathrm{x})$ dengan distribusi teoritisnya $F_{0}(x)$.

Hipotesis:

$H_{0}: F(x)=F_{0}(x) \quad$ (Data mengikuti distribusi teoritis $F_{0}(x)$ )

$H_{1}: F(x) \neq F_{0}(x)$ (Data tidak mengikuti distribusi teoritis $F_{0}(x)$ )

Statistik uji:

$$
D_{\text {hiturg }}=\operatorname{Sup}_{x}\left|S(x)-F_{0}(x)\right|
$$

Keterangan:

$S(x)$ : nilai kumulatif distribusi empiris

$F_{0}(x)$ : nilai kumulatif distribusi teoritis

Uji Kolmogorov-Smirnov akan menghasilkan keputusan tolak $H_{0}$ jika $D_{\text {hitung }}>D_{\text {tabel }}[9]$.

\section{G. Value at Risk}

VaR didefinisikan sebagai nilai harapan rugi maksimum (maximum expected loss) dari nilai aset atau saham pada suatu periode tertentu dan pada tingkat kepercayaan tertentu [10]. Nilai VaR untuk metode GEV dapat diperoleh dengan rumus sebagai berikut [10].

$$
\left.\operatorname{VaR}_{p(G E V)}=\hat{\mu}+\frac{\hat{\sigma}}{\hat{\zeta}}\left[(-\ln (1-p))^{-\hat{\zeta}}\right)-1\right]
$$

sedangkan perhitungan nilai VaR pada GPD dilakukan berdasarkan persamaan berikut. 


$$
\operatorname{VaR}_{p(G P D)}=\hat{\mu}+\frac{\hat{\sigma}}{\hat{\zeta}}\left[\left(\frac{n}{N u} p\right)^{-\hat{\zeta}}-1\right]
$$

\section{H. Return Saham}

Return saham merupakan hasil (keuntungan atau kerugian) yang diperoleh investor dari suatu investasi saham berupa deviden atau capital gain/loss. Nilai return saham dapat dihitung menggunakan persamaan sebagai berikut [11].

$$
R_{t}=\frac{P_{t}-P_{t-1}}{P_{t-1}}
$$

dengan $R_{t}=$ nilai return pada waktu ke-t, $P_{t}=$ harga saham pada waktu ke-t, $P_{t-1}=$ harga saham pada waktu ke-(t-1).

\section{Backtesting}

Pengujian validitas atau backtesting adalah pengujian secara berurutan dari model yang telah digunakan terhadap keadaan yang sebenarnya untuk menguji ketepatan dari prediksi yang telah ditetapkan [12]. Perhitungan backtesting dapat dilihat pada persamaan (13) sebagai berikut.

$$
I_{\tau, t}= \begin{cases}1, & r_{t}<-V a R_{\tau, t} \\ 0, & r_{t} \geq-V a R_{\tau, t}\end{cases}
$$

Model VaR tidak akurat jika nilai estimasi VaR yang dihasilkan lebih besar (overfitting) atau lebih kecil (underfittingi) dibandingkan dengan nilai realized return pada periode ke- $(\mathrm{t}+1)$.

\section{METODOLOGI PENELITIAN}

\section{A. Sumber Data}

Data yang digunakan dalam penelitian ini adalah data sekunder berupa harga penutupan (closing price) saham harian periode 03 Januari 2011 sampai dengan 28 Februari 2017 yang diperoleh dari website finance.yahoo.com. Harga penutupan dipilih karena biasanya digunakan sebagai indikator harga pembukaan untuk hari berikutnya.

\section{B. Variabel Penelitian}

Variabel yang digunakan pada penelitian ini dapat dilihat pada Tabel 1 sebagai berikut.

Tabel 1.

Variabel Penelitian

\begin{tabular}{cc}
\hline \hline Variabel & Keterangan \\
\hline $\mathrm{Z}_{1, \mathrm{t}}$ & Return saham Bank 1 \\
$\mathrm{Z}_{2, \mathrm{t}}$ & Return saham Bank 2 \\
$\mathrm{Z}_{3, \mathrm{t}}$ & Return saham Bank 3 \\
$\mathrm{Z}_{4, \mathrm{t}}$ & Return saham Bank 4 \\
\hline \hline
\end{tabular}

\section{Langkah Analisis}

Langkah analisis yang dilakukan dalam penelitian ini adalah sebagai berikut:

1. Menghitung nilai return saham dengan persamaan (12).

2. Mendeskripsikan return Bank 1, Bank 2, Bank 3, dan Bank 4, serta mengidentifikasi adanya heavy tail.

3. Pengambilan data ekstrem metode Block Maxima dengan membuat blok, satu blok terdiri dari 5 data return.

4. Melakukan uji kesesuaian distribusi metode Block Maxima.
5. Mencari estimasi parameter untuk metode Block Maxima.

6. Menetukan nilai Value at Risk berdasarkan persamaan (10).

7. Pengambilan data ekstrem metode Peaks Over Threshold dengan menentukan threshold sebesar $20 \%$ dari keseluruhan data.

8. Uji kesesuaian distribusi metode Peaks Over Threshold.

9. Menaksir estimasi parameter untuk metode Peaks Over Threshold.

10. Menetukan nilai Value at Risk sesuai persamaan (11).

11. Melakukan perbandingan akurasi dari hasil nilai Value at Risk antara metode Block Maxima dan Peaks Over Threshold.

\section{ANALISIS DAN PEMBAHASAN}

\section{A. Karakteristik Saham Perusahaan Perbankan}

Harga saham penutupan (closing price) merupakan harga dasar yang seringkali digunakan sebagai dasar dalam perhitungan risiko. Pergerakan harga saham dari tahun ke tahun dapat dilihat secara visual dengan menggunakan time series plot. Berikut adalah time series plot harga saham penutupan dari ke-empat Bank yang digunakan dalam penelitian.

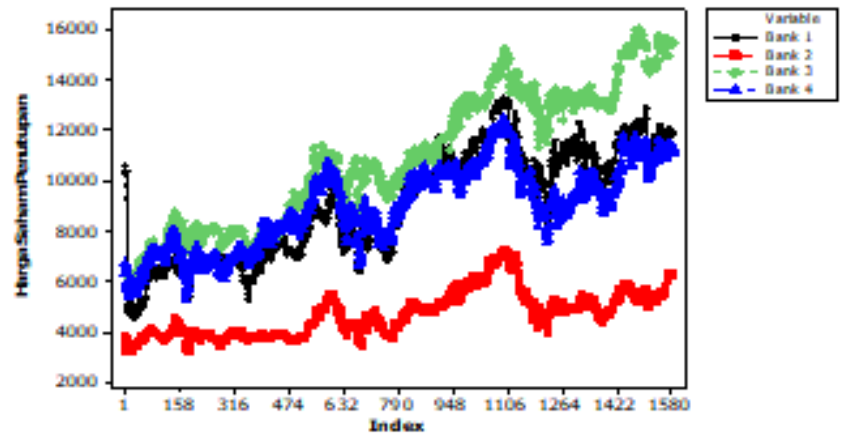

Gambar 1. Time Series Plot Harga Saham Penutupan.

Berdasarkan Gambar 1 menunjukkan bahwa harga saham penutupan berfluktuasi dari waktu ke waktu. Harga saham keempat Bank memiliki kisaran nilai yang berbeda-beda. Dapat diketahui bahwa Bank 3 memiliki harga saham yang paling tinggi, sedangkan Bank 2 memiliki harga saham yang paling rendah. Pola perkembangan harga saham dari empat Bank tersebut cenderung memiliki pola yang hampir sama, dimana jika terjadi kenaikan atau penurunan harga saham, maka empat Bank tersebut juga mengalami kenaikan atau penurunan harga saham. Karakteristik dari harga saham penutupan juga dapat dilihat pada Tabel 2 berikut ini.

Tabel 2.

Statistika Deskriptif Harga Saham Penutupan

\begin{tabular}{crrrr}
\hline \hline Ukuran & \multicolumn{1}{c}{ Bank 1 } & \multicolumn{1}{c}{ Bank 2 } & \multicolumn{1}{c}{ Bank 3 } & \multicolumn{1}{c}{ Bank 4 } \\
\hline Mean & $9.068,2$ & $4.709,4$ & 10.895 & $8.944,4$ \\
Variance & 4.947 .817 & $822.278,7$ & 7.404 .731 & 2.708 .598 \\
Minimum & 4.550 & 3.175 & 5.400 & 5.300 \\
Maximum & 13.275 & 7.275 & 16.050 & 12.475 \\
\hline \hline
\end{tabular}


Tabel 2 menjelaskan karakteristik harga saham secara lebih spesifik. Pada tabel tersebut menunjukkan bahwa Bank 3 memiliki nilai rata-rata harga saham tertinggi dibanding dengan Bank 1, Bank 2, dan Bank 4. Hal tersebut diimbangi dengan nilai maksimum atau minimum saham yang dimiliki Bank 3 memang lebih besar dibanding dengan bank lainnya. Selain itu, harga saham Bank 3 memiliki variasi harga yang paling tinggi. Sebaliknya Bank 2 memiliki keragaman harga saham yang sangat kecil.

Nilai return saham merupakan salah satu indikator dalam melakukan investasi, dimana seorang investor tentunya menginginkan nilai return yang tinggi dengan tingkat risiko yang rendah. Berikut adalah kondisi dari return saham dari perusahaan Bank 1, Bank 2, Bank 3, dan Bank 4.

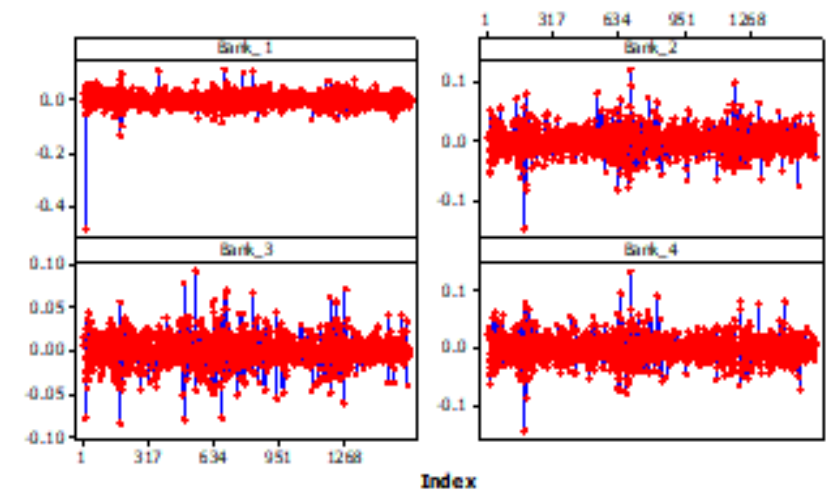

Gambar 2. Time Series Plot Return Saham.

Pada Gambar 2 menunjukkan bahwa return saham pada keempat perusahaan Bank sangat berfluktuatif. Return Bank 1, Bank 2, Bank 3, maupun Bank 4 terlihat bahwa sering terjadi return yang terlalu tinggi maupun return yang terlalu rendah. Selain itu terdapat satu return Bank 1 yang mencapai -0,483 hal tersebut terjadi akibat dari stock split, namun setelah itu return Bank 1 kembali stabil. Fluktuasi yang terjadi pada return Bank 1, Bank 2, Bank 3, dan Bank 4 menyebabkan terjadinya nilai ekstrem pada periode waktu tertentu.

Statistika deskriptif dari return saham dapat dilihat pada Tabel 3 sebagai berikut.

Tabel 3.

Statistika Deskriptif Return Saham

\begin{tabular}{ccccc}
\hline \hline Ukuran & Bank 1 & Bank 2 & Bank 3 & Bank 4 \\
\hline Mean & 0.00042 & 0.00052 & 0.00068 & 0.00058 \\
Variance & 0.00059 & 0.00041 & 0.00026 & 0.00043 \\
Minimum & -0.48387 & -0.14839 & -0.08387 & -0.14516 \\
Maximum & 0.11806 & 0.12329 & 0.09179 & 0.13669 \\
\hline \hline
\end{tabular}

Berdasarkan Tabel 3 dapat diketahui bahwa rata-rata nilai return saham Bank 3 lebih tinggi dari nilai return saham Bank lainnya, dengan diikuti nilai varians yang lebih kecil. Hal ini menunjukkan bahwa return saham Bank 3 lebih stabil dan tidak terlalu mengalami perubahan yang besar dari waktu ke waktu. Begitu sebaliknya dengan Bank 1, dimana nilai ratarata return kecil sedangkan variansnya paling besar. Sedangkan untuk return Bank 2 dan Bank 4 memiliki stabilitas nilai return yang hampir sama.

Sebagian besar data financial memiliki ekor distribusi yang heavy tail, yaitu ekor distribusi yang turun secara lambat dibandingkan dengan distribusi normal. Hal tersebut mengakibatkan peluang terjadinya nilai ekstrem akan lebih besar. Untuk mengidentifikasi adanya nilai ekstrem pada data return saham dapat dilakukan dengan menggunakan Boxplot, dimana hasilnya dilihat berdasarkan Gambar 3 berikut ini.

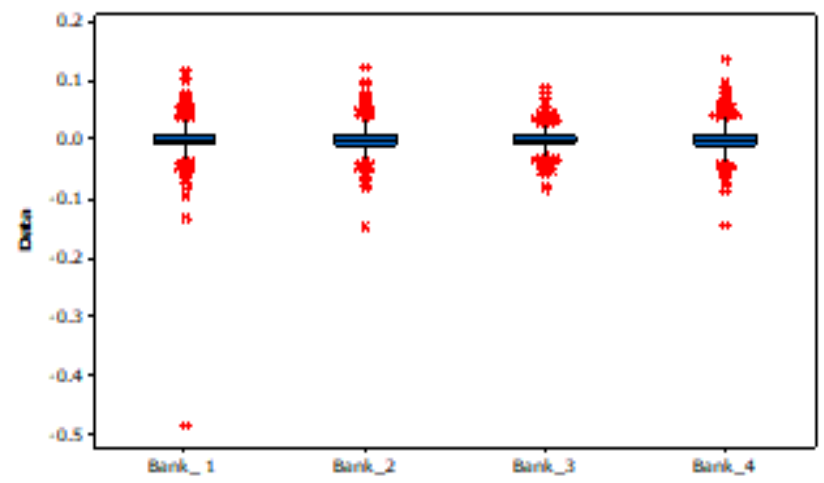

Gambar 3. Boxplot Return Saham.

Berdasarkan Gambar 3 diketahui bahwa nilai return saham Bank 1, Bank 2, Bank 3, dan Bank 4 memiliki nilai-nilai ekstrem. Keberadaan nilai ekstrem dapat diketahui dari adanya titik-titik berwarna merah.

Selain menggunakan boxplot, dapat pula dibuktikan dengan uji kesesuaian distribusi menggunakan uji KolmogorovSmirnov dimana distribusi teoritis yang diharapkan adalah distribusi normal dan taraf signifikan yang digunakan adalah 5\% $(\alpha=0,05)$. Tabel 4 merupakan ringkasan dari hasil uji Kolmogorov-Smirnov untuk data return semua bank.

Tabel 4.

Hasil Uji Kolmogorov-Smirnov

\begin{tabular}{ccccc}
\hline \hline Perusahaan & D hitung & D tabel & $P$-value & Keputusan \\
\hline Bank 1 & 0,114 & 0,034 & $<0,01$ & Tolak $H_{0}$ \\
Bank 2 & 0,100 & 0,034 & $<0,01$ & Tolak $H_{0}$ \\
Bank 3 & 0,099 & 0,034 & $<0,01$ & Tolak $H_{0}$ \\
Bank 4 & 0,0084 & 0,034 & $<0,01$ & Tolak $H_{0}$ \\
\hline \hline
\end{tabular}

Berdasarkan Tabel 4, data return keempat bank memiliki nilai $D_{\text {hitung }}$ yang lebih besar dari $D_{\text {tabel }}$, selain itu $p$-value dari semua data return bank memiliki nilai yang kurang dari alfa 0,05 sehingga didapatkan keputusan tolak $H_{0}$ yang artinya data tidak mengikuti distribusi normal.

\section{B. Pemodelan Block Maxima}

Pemodelan return saham dengan pendekatan Block Maxima meliputi uji kesesuaian distribusi dan menghitung estimasi parameter. Adapun konsep yang dimiliki adalah membagi data ke dalam blok yang sama besar, dan mengambil nilai ekstrem yang ada pada setiap blok untuk dilakukan analisis.

\section{1) Uji Kesesuaian Distribusi}

Identifikasi awal sebelum melakukan perhitungan estimasi parameter yaitu memastikan bahwa data ekstrem yang diperoleh dari pengambilan nilai ekstrem pada masing-masing blok mengikuti distribusi Generalized Extreme Value (GEV). Berikut adalah hasil dari pengujian kesesuaian distribusi dengan menggunakan Uji Kolmogorov-Smirnov. 
Tabel 5.

Uji Kolmogorov-Smirnov Block Maxima

\begin{tabular}{cccc}
\hline \hline Perusahaan & D hitung & D tabel & Keputusan \\
\hline Bank 1 & 0,056 & 0,076 & Gagal Tolak $H_{0}$ \\
Bank 2 & 0,053 & 0,076 & Gagal Tolak $H_{0}$ \\
Bank 3 & 0,049 & 0,076 & Gagal Tolak $H_{0}$ \\
Bank 4 & 0,030 & 0,076 & Gagal Tolak $H_{0}$ \\
\hline \hline
\end{tabular}

Berdasarkan hasil pengujian pada Tabel 5, dapat diketahui bahwa masing-masing variabel menghasilkan nilai $D_{\text {hitung }}$ yang lebih kecil dari $D_{\text {tabel }}$. Selain itu, dengan menggunakan alfa sebesar $5 \%$ diperoleh keputusan gagal tolak $H_{0}$, yang artinya bahwa data ekstrem yang digunakan telah mengikuti distribusi teoritis, yaitu distribusi GEV.

2) Estimasi Parameter Block Maxima

Perhitungan estimasi parameter metode Block Maxima adalah menggunakan data ekstrem yang telah diperoleh sebelumnya dan telah dilakukan pengujian kesesuaian distribusi. Hasil estimasi parameter ditampilkan dalam Tabel 6 sebagai berikut.

Tabel 6.

Estimasi Parameter Block Maxima

\begin{tabular}{ccccc}
\hline \hline Parameter & Bank1 & Bank2 & Bank3 & Bank4 \\
\hline Banyaknya Blok & 317 & 317 & 317 & 317 \\
Bentuk $(\xi)$ & 0.182 & 0.111 & -0.022 & 0.115 \\
Lokasi $(\mu)$ & 0.014 & 0.015 & 0.012 & 0.015 \\
Skala $(\sigma)$ & 0.012 & 0.012 & 0.011 & 0.012 \\
\hline \hline
\end{tabular}

Tabel 6 menunjukkan bahwa banyaknya blok yang terbentuk adalah 317 blok dengan banyaknya pengamatan tiap blok adalah 5 pengamatan. Hasil estimasi parameter menunjukkan bahwa besarnya parameter bentuk yang terbesar dimiliki oleh Bank 1, hal ini menyatakan bahwa perilaku ekor kanan Bank 1 semakin berat (heavy tail) sehingga peluang terjadinya nilai ekstrem akan semakin besar dibanding dengan bank lainnya. Estimasi parameter lokasi yang dihasilkan menyatakan letak titik pemusatan data, sedangkan parameter skala menjelaskan keragaman data.

Berdasarkan hasil estimasi parameter yang diperoleh, maka dihasilkan hasil estimasi nilai VaR sebagai berikut.

Tabel 7.

Estimasi Nilai VaR Block Maxima

\begin{tabular}{cccc}
\hline \hline Perusahaan & Ukuran & Risiko & Profit \\
\hline \multirow{2}{*}{ Bank 1 } & Mean & -0.0604 & 0.0604 \\
& Variance & 0.0002 & 0.0002 \\
Bank 2 & Mean & -0.0555 & 0.0555 \\
& Variance & 0.0002 & 0.0002 \\
Bank 3 & Mean & -0.0439 & 0.0439 \\
& Variance & 0.0001 & 0.0001 \\
Bank 4 & Mean & -0.0567 & 0.0567 \\
& Variance & 0.0002 & 0.0002 \\
\hline \hline
\end{tabular}

Pada Tabel 7 diatas, dapat diketahui bahwa dengan menggunakan metode Block Maxima dan tingkat keyakinan 95\% seorang investor yang menginvestasikan dananya sebesar Rp 1.000.000.000,- pada saham Bank 1 akan mengalami kerugian maksimum sebesar Rp 60.400.000,- yang merupakan hasil perkalian antara jumlah investasi dengan tingkat resiko. Hal ini dapat juga dikatakan terdapat kemungkinan sebesar 5\% bahwa investor akan mengalami kerugian minimum sebesar Rp 60.400.000,-. Demikian halnya jika seorang investor berinvestasi Rp 1.000.000.000,- di Bank 2 maka akan mengalami kerugian minimum sebesar Rp 55.500.000,sedangkan di Bank 3 dan Bank 4 akan mengalami kerugian minimum sebesar Rp 43.900.000,- dan Rp 56.700.000,sehingga dapat disimpulkan bahwa kemungkinan seorang investor mengalami kerugian yang lebih besar adalah jika berinvestasi di Bank 1.

Selain untuk mengetahui estimasi risiko, Tabel 7 juga dapat diperoleh informasi mengenai estimasi keuntungan untuk masing-masing bank. Tingkat risiko yang diterima oleh seorang investor akan berbanding lurus dengan tingkat keuntungan yang diperoleh. Pada tabel tersebut dapat diketahui bahwa saham Bank 1 memberikan tingkat keuntungan yang lebih besar, yakni apabila seorang investor berinvestasi sebesar Rp 1.000.000.000,- maka dengan tingkat keyakinan $95 \%$, investor tersebut akan menerima keuntungan sebesar Rp 60.400.000,--

\section{Pemodelan Peaks Over Threshold}

Pendekatan lainnya yang dapat digunakan untuk mengidentifikasi nilai ekstrem dalam suatu data yaitu pendekatan Peaks Over Threshold. Konsep dari pendekatan ini adalah mengidentifikasi nilai ekstrem dengan cara menetapkan batas atau threshold. Data yang melebihi nilai threshold dianggap sebagai nilai ekstrem.

1) Uji Kesesuaian Distribusi

Pengujian asumsi distribusi dilakukan dengan menggunakan uji Kolmogorov-Smirnov. Pengujian asumsi distribusi dilakukan karena perhitungan estimasi risiko (VaR) pada penelitian ini berdasarkan pada distribusi yang menaungi data ekstrem.

Tabel 8.

Uji Kolmogorov-Smirnov Peaks Over Threshold

\begin{tabular}{cccc}
\hline \hline Perusahaan & D hitung & D tabel & Keputusan \\
\hline Bank 1 & 0,046 & 0,076 & Gagal Tolak $H_{0}$ \\
Bank 2 & 0,040 & 0,076 & Gagal Tolak $H_{0}$ \\
Bank 3 & 0,061 & 0,076 & Gagal Tolak $H_{0}$ \\
Bank 4 & 0,039 & 0,077 & Gagal Tolak $H_{0}$ \\
\hline \hline
\end{tabular}

Tabel 8 merupakan hasil dari uji kesesuaian distribusi dari nilai ekstrem dengan metode Peaks Over Threshold, dimana menghasilkan keputusan gagal tolak $H_{0}$ baik untuk Bank 1, Bank 2, Bank 3, maupun Bank 4. Hal ini karena nilai $D_{\text {hitung }}<D_{\text {tabel }}$, sehingga dapat disimpulkan bahwa data nilai ekstrem telah mengikuti distribusi GPD.

2) Estimasi Parameter Peaks Over Threshold

Tabel 9 berikut ini merupakan hasil estimasi parameter yang dihasilkan oleh metode Peaks Over Threshold. 
Tabel 9.

Estimasi Parameter Peaks Over Threshold

\begin{tabular}{ccccc}
\hline \hline Parameter & Bank1 & Bank2 & Bank3 & Bank4 \\
\hline Threshold $(\mathrm{u})$ & 0,014 & 0,013 & 0,011 & 0,014 \\
Jumlah Pengamatan $(\mathrm{n})$ & 1585 & 1585 & 1585 & 1585 \\
Jumlah Pengamatan diatas & 318 & 317 & 317 & 316 \\
Threshold $(\mathrm{Nu})$ & 0,119 & 0,072 & 0,070 & 0,061 \\
Bentuk $(\xi)$ & 0,013 & 0,013 & 0,010 & 0,014 \\
Skala $(\sigma)$ & & & & \\
\hline \hline
\end{tabular}

Hasil estimasi parameter bentuk $(\xi)$ menunjukkan perilaku ekor dari data ekstrem, dimana semakin besar nilai $\xi$ maka peluang terjadinya nilai ekstrem akan semakin besar pula. Sedangkan untuk parameter skala $(\sigma)$ menunjukkan keragaman nilai ekstrem.

Nilai estimasi parameter yang diperoleh pada Tabel 9, digunakan untuk menghitung estimasi nilai risiko. Tabel 10 berikut ini menunjukkan hasil nilai risiko untuk masingmasing bank.

Tabel 10.

Estimasi Nilai VaR Peaks Over Threshold

\begin{tabular}{cccc}
\hline \hline Perusahaan & Ukuran & Risiko & Profit \\
\hline \multirow{2}{*}{ Bank 1 } & Mean & -0.0468 & 0.0468 \\
& Variance & 0.0001 & 0.0001 \\
Bank 2 & Mean & -0.0444 & 0.0444 \\
& Variance & 0.0001 & 0.0001 \\
Bank 3 & Mean & -0.0332 & 0.0332 \\
& Variance & 0.0001 & 0.0001 \\
Bank 4 & Mean & -0.0431 & 0.0431 \\
& Variance & 0.0001 & 0.0001 \\
\hline \hline
\end{tabular}

Berdasarkan tabel diatas, diketahui bahwa pada tingkat keyakinan 95\% seorang investor yang menanamkan modalnya ke Bank 1 sebesar Rp 1.000.000.000,- maka akan mengalami kerugian maksimum sebesar Rp 46.800.000,-. Begitu pula apabila seorang investor akan mananamkan modal ke Bank 2 maka dengan tingkat keyakinan $95 \%$ akan mendapatkan kerugian sebesar Rp 44.400.000,- sedangkan kerugian di Bank 3 adalah sebesar Rp 33.200.000,- dan di Bank 4 sebesar Rp 43.100.000,-.

Berdasarkan hasil dari estimasi tingkat keuntungan yang dihasilkan, Bank 1 memberikan keuntungan yang paling besar, yaitu sekitar $\mathrm{Rp} 46.800 .000,-$. Perusahaan yang memberikan keuntungan terbesar kedua yaitu Bank 2, dilanjutkan dengan Bank 4, dan Bank 3.

\section{Perbandingan Metode Pendekatan VaR}

Berdasarkan hasil estimasi risiko dan profit, maka untuk mengetahui akurasi antara kedua metode dapat diketahui dengan menggunakan backtesting seperti pada Tabel 11 dan Tabel 12.

Hasil backtesting menunjukkan bahwa nilai loss dan expected shortfall yang dihasilkan oleh metode BM lebih kecil dibanding menggunakan metode POT. Estimasi risiko dengan metode BM memiliki selisish yang cukup jauh dari kuantil $5 \%$, hal ini mengindikasikan estimasi VaR pada keempat perusahaan tersebut cenderung underestimate. Secara keseluruhan, metode POT memiliki selisih yang lebih kecil sehingga dapat disimpulkan lebih akurat dibanding metode BM.

Tabel 11. Hasil Backtesting Estimasi Risiko

\begin{tabular}{ccccccc}
\hline \hline \multirow{2}{*}{ Saham } & \multicolumn{3}{c}{ Loss } & \multicolumn{2}{c}{$\begin{array}{c}\text { Expected } \\
\text { Shortfall }\end{array}$} & $\mid$ Selisih $\mid$ \\
\cline { 2 - 7 } & BM & POT & BM & POT & BM & POT \\
Bank 1 & 12 & 35 & $0,9 \%$ & $2,6 \%$ & $4,1 \%$ & $2,4 \%$ \\
Bank 2 & 11 & 30 & $0,8 \%$ & $2,2 \%$ & $4,2 \%$ & $2,8 \%$ \\
Bank 3 & 16 & 39 & $1,2 \%$ & $2,9 \%$ & $3,8 \%$ & $2,1 \%$ \\
Bank 4 & 18 & 38 & $1,4 \%$ & $2,8 \%$ & $3,6 \%$ & $2,2 \%$ \\
\hline \hline
\end{tabular}

Tabel 12.

Hasil Backtesting Estimasi Profit

\begin{tabular}{ccccccc}
\hline \hline \multirow{2}{*}{ Saham } & \multicolumn{3}{c}{ Loss } & \multicolumn{2}{c}{$\begin{array}{c}\text { Expected } \\
\text { Shortfall }\end{array}$} & $\mid$ Selisih| \\
\cline { 2 - 7 } & BM & POT & BM & POT & BM & POT \\
Bank 1 & 13 & 31 & $1 \%$ & $2,3 \%$ & $4 \%$ & $2,7 \%$ \\
Bank 2 & 20 & 34 & $1,5 \%$ & $2,5 \%$ & $3,5 \%$ & $2,5 \%$ \\
Bank 3 & 19 & 41 & $1,4 \%$ & $3,1 \%$ & $3,6 \%$ & $1,9 \%$ \\
Bank 4 & 14 & 44 & $1,1 \%$ & $3,1 \%$ & $3,9 \%$ & $1,7 \%$ \\
\hline \hline
\end{tabular}

\section{KESIMPULAN DAN SARAN}

Karakteristik harga saham penutupan maupun return saham pada Bank 3 menunjukkan nilai yang lebih tinggi dibanding Bank 1, Bank 2, dan Bank 4. Sedangkan perusahaan yang memiliki volatilitas return saham tertinggi yaitu Bank 1 . Secara umum, data return yang digunakan memiliki nilai ekstrem dan berpola heavy tail. Berdasarkan metode BM maupun POT, tingkat risiko investasi saham di Bank 1 adalah yang paling tinggi, sedangkan tingkat risiko investasi saham di Bank 3 adalah yang paling rendah. Selain itu, berdasarkan hasil dari backtesting, menunjukkan bahwa metode POT memiliki selisih kuantil yang lebih kecil, sehingga dapat dinyatakan bahwa metode POT lebih baik dibanding metode BM.

Identifikasi kejadian ekstrem menggunakan EVT pada umumnya membutuhkan jumlah data yang besar, terutama untuk metode BM, sehingga data dapat dibagi ke dalam blok yang lebih besar agar data pada setiap blok tidak ada yang bernilai nol atau negative. Pada penelitian selanjutnya disarankan untuk menggunakan jumlah data yang lebih besar serta mempertimbangkan penggunaan variabel lain yang diduga mempengaruhi kondisi saham agar hasil return yang dihasilkan dapat lebih sesuai dengan kondisi yang sebenarnya.

\section{DAFTAR PUSTAKA}

[1] R. Y. Nugroho, "Dampak Fluktuasi Dinamis Makro Ekonomi, IHSG, dan SIBOR terhadap Jakarta Islamic Index," J. Investasi, pp. 76-89, 2011.

[2] W. K. Nastiti, "Estimasi Risiko Investasi Saham Perusahaan Sektor Telekomunikasi di BEI Menggunakan Metode CVaR dan VaR dengan Pendekatan ARMA-GARCH dan EVT," Surabaya, 2016.

[3] Amanda and W. A. Pratomo, "Pengaruh Fundamental dan Risiko Sistematik terhadap Harga Saham Perbankan yang terdaftar pada Indeks LQ45," J. Ekon. dan Keuang., vol. 1, no. 3, 2013. 
[4] P. Jorion, Value at Risk: The New Bencmark for Managing Financial Risk. New York: McGraw-Hill Companies, 2001.

[5] A. K. Singh, P. J. Robert, and D. E. Allen, "Extreme Market Risk and Extreme Value Theory," Extrem. Mark. Risk Extrem. Value Theory, vol. 94, pp. 310-328, 2013.

[6] S. Kotz and S. Nadarajah, Extreme Value Distribution (Theory and Application). London: Imperia College Press, 2002.

[7] A. J. McNeil, Extreme Value Theory for Risk Manager. Department Mathematic ETH Zentrum, 1999.

[8] S. Coles, An Introduction to Statistical Modeling of Extreme Values. London: Springer, 2011.
[9] W. W. Daniel, Statistik Non Parametrik Terapan. Diterjemahkan oleh Alex Tri Kantjono W. Jakarta: PT.Gramedia, 1989.

[10]M. Gilli and E. Kellezi, "An Application of Extreme Value Theory for Measuring Financial Risk," Comput. Econ., vol. 27, no. 1, pp. 1-23, 2006.

[11]J. Franke, W. K. Hardle, and C. M. Hafner, Statistics for Financial Markets. Germany: Springer, 2015.

[12]M. G. Cruz, Modelling Measuring and Hedging Operational Risk. New York: John Wiley \& Sons Inc, 2002. 